\title{
Will Terrorist Attacks on Air Cargo Have an Impact on World Trade? [1]
}

\author{
Thomas Biermann
}

Zusammenfassung

Luftfracht stellt einen wichtigen Teil des zivilen Luftverkehrs dar und spielte eine zentrale Rolle für das Wachstum des Welthandels im Zeitalter der Globalisierung. International tätige Terroristen sind sich mittlerweile dieser Bedeutung bewusst und griffen 2010 von Jemen aus den Luftverkehr erstmals direkt über die Luftfracht an. In diesem Beitrag werden die Besonderheiten der Luftfracht unter dem Blickwinkel der Gefahrenabwehr diskutiert. Es zeigt sich, dass trotz verschärfter Sicherheitsmaßnahmen ein Restrisiko verbleibt - doch könnte ein Überziehen der Sicherheitsanforderungen noch größere Schäden durch ein Abwürgen der Welthandelsströme bewirken.

\section{Abstract}

Air Cargo forms a significant part of civil aviation and played a central role in the growth of world trade in the era of globalisation. International terrorists have become aware of this importance and launched their first direct attack from Yemen in 2010. In this paper the characteristics of air cargo in regard to security issues will be discussed. It can be shown that a certain amount of risk remains in spite of improved protection strategies, but tightening security restrictions too much could have an even worse impact by strangling world trade flows.

\section{Introduction}

Terrorism has been a serious issue for civil aviation since the 1960ies and entered worldwide public awareness in the 1970ies. The events of September 2001 resulted in a severe global tightening of security regarding passengers. Despite a range of creative attempts by terrorists (including hidden bombs in soft drink bottles, shoes and underpants) international aviation has until now dealt successfully with this threat.

But the authorities as well as the general public tend to neglect the vulnerability of the second important part of the aviation business: air cargo. This sector can easily be identified as a new inviting target for attacks. In 2010 the last-minute detection of two bomb packages aboard commercial aircraft showed that terrorists finally have become aware of this angle - forcing security experts to develop innovative solutions in the face of new risks.

Air Cargo forms a backbone of world trade. As airborne logistics are extremely sensitive to disturbances by complicated and time-consuming procedures, protection poses a difficult problem. A specific strategy against terrorist threats has to be built up keeping se- curity needs and the economic benefits of free-flowing world trade in a reasonable balance.

\section{The Air Cargo Business}

\subsection{Air Cargo in Early Aviation History}

Even inside the aviation industry most people are hardly aware of the fact that their business actually began with the transport of goods, starting with mail flights in the USA as early as 1910 with regular routes taken up 1918 in the USA and 1919 in Europe (Wensveen 2007). After World War I some dismissed fighter pilots bought out-of-service planes to offer fast transport for letters, documents and small parcels. Their planes made of strings and textiles were not equipped for passengers and who would have dared to take a ride in such a flimsy construction anyway? It took some years until the mid 1920ies and a new generation of aircraft specifically designed for commercial use in passenger transport to get off the ground (Biermann 1986).

During World War II aircraft proved to be a powerful and reliable mode of transport for people and military goods. They could be used to carry tons of payload over 
very long distances, which was especially important for the US forces fighting on two fronts far away from the mainland. After the war the Berlin airlift operations in 1948/49 helped to overcome the blockade of the city by Soviet block authorities, American and British forces flew in 15000 tons of food, fuel and clothing per day for a period of eleven months.

Ten years later the first long-range airliners with jet engines entered service - giving birth to the modern air cargo business. With a jet it is possible to fly at much higher altitudes $(10-15000 \mathrm{~m})$ than with a propeller, making the cruise more comfortable as the plane is travelling above the clouds and winds. But these aircraft need a pressurized cabin to keep crew and passengers alive. As the pressure inside is higher than outside a considerable amount of stress has to be taken by the fuselage, which must be constructed as a cylindrical tube to minimize the danger of air leakages and breaking seams. A deck for passenger seats has to be installed, leaving unused space underneath. Airlines offer this space for cargo transport to generate extra revenue on flights already paid for by the passengers (Morrell 2011).

\subsection{Air Cargo in the Wide-Body Age}

Up to the 1970ies air cargo was still very expensive and an option only for shippers with an absolute priority on speed (Chiavi 2005) like emergency deliverance (important spare parts for example), perishables (fresh seafood) or extremely valuable goods (works of art). In 1970 the first wide-body aircraft took up commercial service. With a cross-section diameter of 6,50 $\mathrm{m}$ - in comparison to less than $4 \mathrm{~m}$ in a conventional narrow-body model - the Boeing 747 could seat up to ten passengers in one row giving a total capacity of more than 500 seats. In creasing the fuselage diameter increased the belly space underneath the main deck significantly.

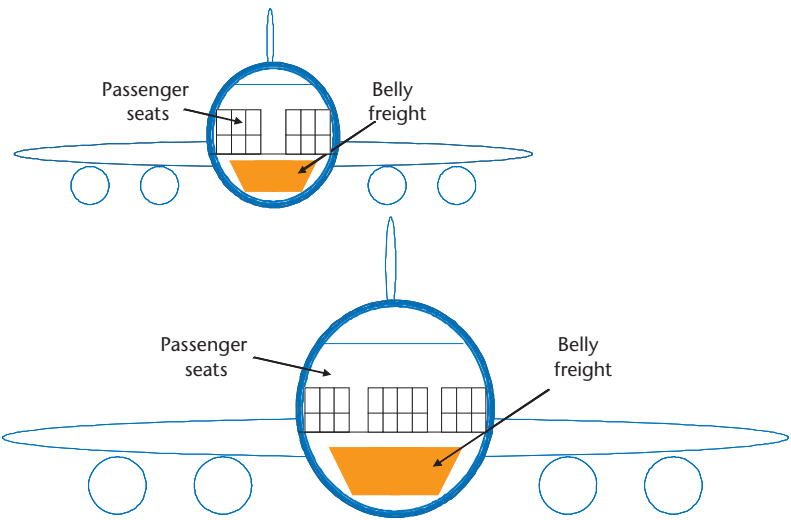

Fig. 1: Belly Freight - Narrow-Body and Wide-Body Aircraft
With wide-body aircraft dominating the intercontinental routes the additional supply of air cargo capacity brought the freight rates down to a level at which air transport could compete successfully with sea shipping. In several markets the demand was big enough to allow pure freighter operations in an all-cargo version of the Boeing 747 with a payload capacity of 100 tons. As a third option the so-called combi version featured passenger seats in the front section of the plane and an additional cargo compartment in the back of the main deck with a special side cargo door (Morrell 2011).

\subsection{Air Cargo and Globalisation}

In spite of a steep decline of air cargo rates since the introduction of wide-body aircraft - they are now less than half the amount in real terms in comparison to 1969 (Boeing 2010) - sending a container by air still is up to ten times more expensive than maritime transport. But taking into account the capital cost of the inventory taking the slow route aboard a ship shippers will profit by choosing air cargo whenever their goods have a high value per kilogram, for example electronics, machinery and even toys and fashionable textiles (Reinhold et al. 2011). The modal split share of air cargo in international trade regarding tonnage still looks tiny ( $2 \%)$, but its share of the value of transported goods is $35-40 \%$ of the total international trade turnover (WTO data given by Pompl 2007).

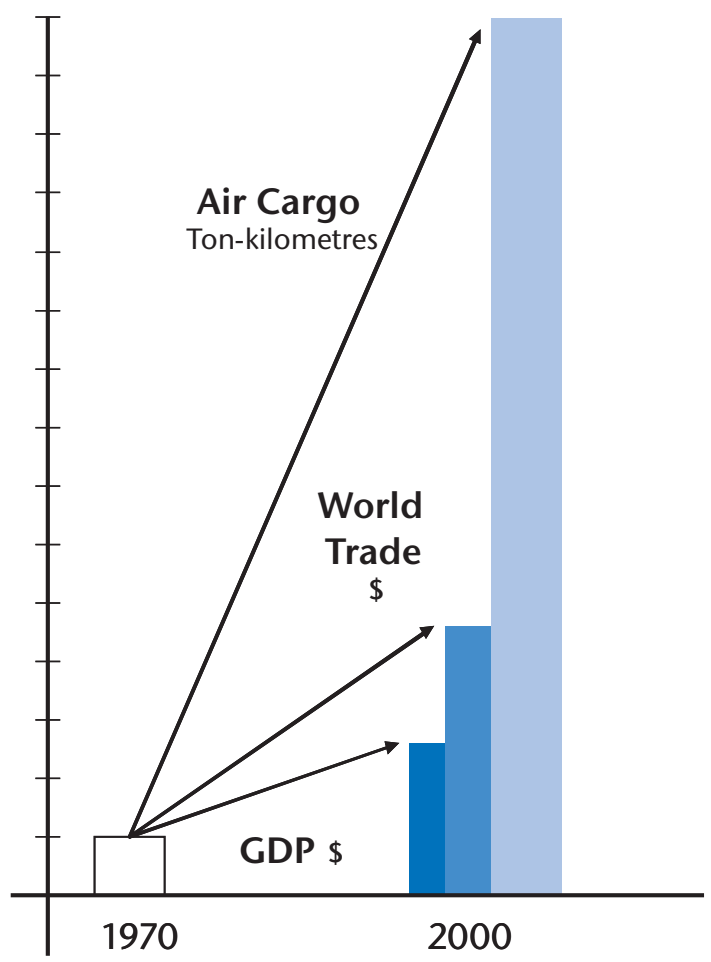

Fig. 2: Relative Growth GDP/World Trade/Air Cargo 


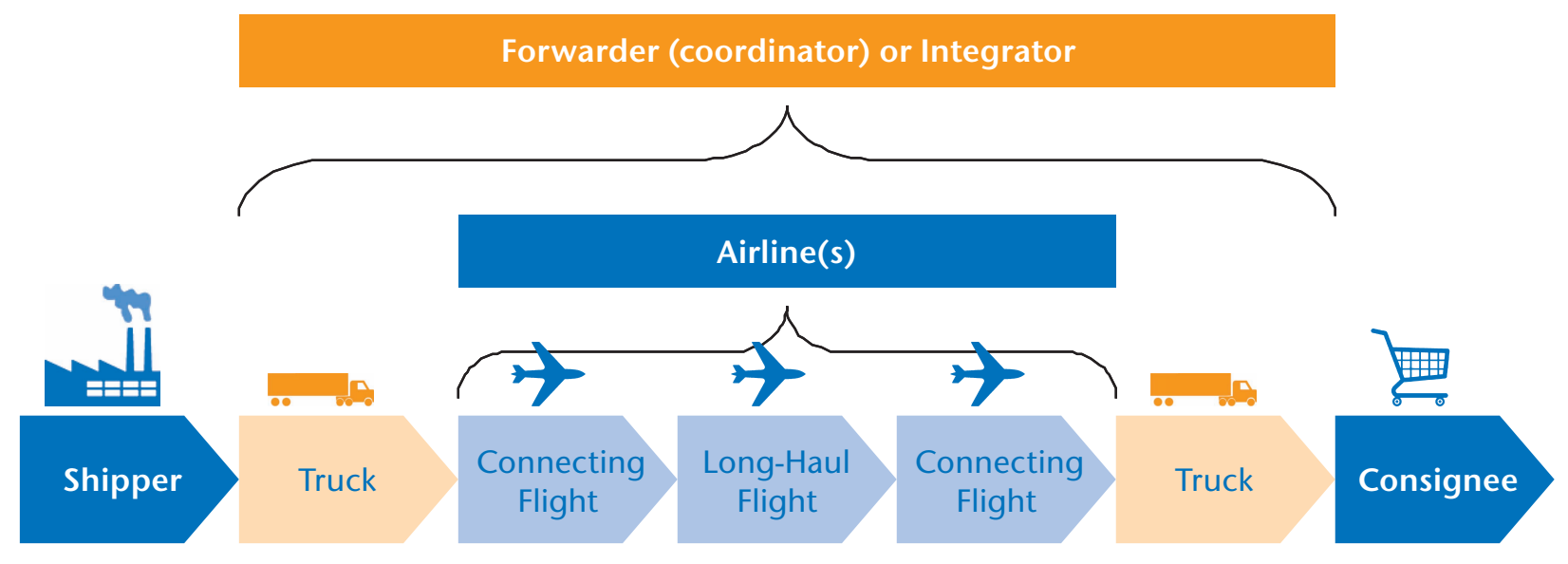

Fig. 3: The Air Cargo Transport Chain

According to World Bank statistics in the 30 year period 1970 - 2000 world GDP (gross domestic product) grew by $154 \%$ (price adjusted $\$$ ), the trade volume by $355 \%$ (dito) and the air cargo volume (measured in freight ton-kilometres) by $1395 \%$ (Kasarda et al. 2004). For the future we may expect air cargo traffic volume to triple again in the next 20 years with the highest growth rates in the markets to/from and inside Asia (Boeing 2010).

The majority of airlines with a long haul network carry belly freight in their passenger planes and some also operate all-cargo aircraft (e.g. Lufthansa, Air France, Cathay Pacific). There also exists a number of independent cargo airlines flying freighters exclusively (e. g. Cargolux, CAL, Jade). Integrators offering transport chains including ground transport and distribution (as UPS, FedEx, DHL and TNT) have specialized on fast and reliable regular express transport of parcels which can be handled by one man alone without special equipment - their average shipment weight is only $5.3 \mathrm{~kg}$. For many customers in manufacturing and services these integrators figure as a main element in their justin-time logistics (Boeing 2010).

\section{Aviation and Terrorism}

\subsection{Moving Targets}

Aircraft share a curious fate with other new modes of transport in history: they attracted the attention of criminals as soon as the general public started to get aboard. Prohibition-time gangsters in the USA were early adaptors of light airplanes for smuggling or escaping. Hi-jacking of an airplane - getting illegitimate access by violently disposing of the original owners - was first observed in a revolution in Peru in 1931. Entering the flight-deck of an airliner with a weapon and forcing the pilot to change his course became rather common from 1958 onwards. About five incidents per year were recorded until 1967 and grew to 38 in 1968 and a historic peak of 82 cases in 1969. Until 1977 the average annual number of »sky-jackings « was an astonishing 41 per year (www.wikipedia.com).

This phenomenon is easy to understand by thinking from a »black hat « point of view, as an airliner has a high symbolic value. The passengers will usually comprise a certain number of high-status people and therefore can be used as »bargaining chips « if taken hostage. Because during flight an aircraft (especially a pressurized jet) is extremely vulnerable to damage, even small a handgun forms a convincing threat aboard.

\subsection{Motivation and Opportunity}

The motives for a hi-jacking include frustrated employees and desperate lunatics (Schiehll 2002), but political motives play a major role in most cases in aviation. During the Cold War a hi-jacked plane crossing the Iron Curtain was regarded as a propaganda victory by the receiving country. US planes were taken over and redirected to Cuba, but there were Cuban fugitives as well diverting planes to the United States, where they could hope to be celebrated as heroes. A similar situation was observed in the China/Taiwan conflict (www.airdisaster.com). From 1968 onwards the Israeli national airline $\mathrm{El} \mathrm{Al}$ became a prime target for Palestine terrorist attempts. The main objective at that time was to use aircraft, passengers and crew in exchange for imprisoned comrades in Israel or Europe.

The bargaining position of the terrorists is strongest while the aircraft is airborne. The aviation security 
experts across the world therefore agreed to a common strategy stipulating that the safest way to deal with »skyjacking « was to instruct the crew to fulfil all requests of armed offenders until the aircraft was safely sitting at an airport - any airport. Code words were distributed to flight crews and air traffic controllers to signal highjacking details via normal in-flight communication routines without the perpetrators' knowledge. After landing the security forces would negotiate for the freedom of the hostages while preparing a surprise counter-attack with special troops and a fair chance to save innocent life. Famous counter-attack/rescue operations in Entebbe (Uganda) by Israeli in 1976 and Mogadishu (Somalia) by German special forces in 1977 demonstrated the viability of this approach (www.aviationsafety.net).

\subsection{Total Destruction}

Total destruction of an aircraft en-route by a bomb hidden in the luggage compartment in a suitcase primed to explode at a certain time or altitude also has a sad long history starting with a suspected gangland murder in 1933. But today in this type of crime the motive usually also is a political one. Recent bombings or attempted bombings were performed by Palestine terrorists or their supporters targeting Israel and its allies, mainly the USA. The destruction of a Pan American Boeing 747 with 270 victims in the airspace above Lockerbie (Scotland) in 1988 is the best known example. But terrorists from India and North Korea have also managed to bring down airliners in a spectacular manner 1985 and 1987 respectively (www.aviation-safety.net).

Counter-measures against a bomb in the luggage-department or a carry-on bag were developed mainly by Israeli security experts. Their starting point was a strict policy that no suitcase should travel aboard without its rightful owner sitting in that aircraft and probing whether a third party had an opportunity to hide an explosive device in a suitcase. Passengers travelling to or from Israel have to endure an intensive interview with officers specially trained to observe involuntary facial »microexpressions « before checking in their suitcases. Screening bags and people by X-Ray (and by hand in case of suspicion) is international standard procedure now, but Israeli security agents also put every bag into a decompression chamber to cause an eventual pressuredirected device to ignite. In spite of being the number one target for decades no $\mathrm{El} \mathrm{Al} \mathrm{aircraft} \mathrm{has} \mathrm{come} \mathrm{to} \mathrm{harm}$ from a terrorist attack since 1970.

\subsection{The Last Resort: Suicide Attacks}

The chosen counter-counter strategy of the terrorists looks like a pretty desperate effort to the rational European: the suicide attack. Clutching your enemy and going down with him has no precedence in Western warfare - except in some rare instances where the heroes did not have a realistic survival alternative anyway. The history of planned voluntary suicide attacks in modern times has been restricted to the Kamikaze pilots in Japan during the last stages of World War II besides some isolated cases of madmen running amok in the hope of being killed in the course of their action.

Until 2001 security experts in Western countries regarded the suicide attack as an option only for a small number of half-crazy people without education and no future job or status perspectives against easy-toreach targets on the ground. The high-tech arena of international aviation was regarded as practically immune against the approach of a farm boy with a rucksack filled with explosives and nails. Common wisdom maintained that a clever terrorist would always look for an escape route for himself - a suicidal terrorist by definition was a nitwit unable to get near a promising target. Even in a highly hierarchical organized and religiously motivated extremist group a well trained intelligent warrior would be much too valuable to waste in a kamikaze-like assault.

In September 2001 this conviction was shaken, as a group of 19 jihadists hi-jacked four airliners in the USA simultaneously and transformed them into weapons by flying two of them into the World Trade Centre in New York City and one into the Pentagon building in Washington, D.C., losing the fourth (also re-directed towards Washington, D.C.) to a surprise recapture attempt of passengers resulting in a crash in an open field in Pennsylvania.

This dramatic multiple hit pattern shattered the dogma that a sophisticated terrorist will never operate without an escape route. Intelligent suicide bombers with specialist training (e.g. in piloting) formed a threat against which no remedy was known (Brown 2010). Fortunately no further attacks of the 2001 calibre have occurred. In the last decade several suicidal attempts against aviation failed or were prevented because the perpetrators proved to be not up to their task restoring some reputation to the »suicidal-simpleton «dogma. The shoe-bomber of December 2001 aboard an American Airlines flight from Paris to Miami unsuccess- 
fully tried three times to light up the explosive material hidden in his footwear until the cabin crew stopped him (www.aviation-safety.net).

\section{How to Cope with Terrorism in Aviation}

\subsection{Three Walls}

Aviation nowadays is protected by three »city walls«. First there is a general police look-out for any kind of potential terrorists by telephone surveillance or recruiting informers. The middle wall is the entrance control to the sensitive areas at the airport and the inner wall is the citadel inside the airplane: the reinforced door to the flight deck (possibly watched by armed air-marshals) forms the last barrier to a World-Trade-Centre type of attack.

The most important aviation-specific defence measure is the second one: sealing off sensitive airport areas. There is a well guarded borderline between the "airside« (the airfield and parts of the terminal as for example departure gates) and the uncritical »land-side«. Passing into the air-side area is feasible only at specific transfer points, where passengers, crews and airport workers will be checked for weapons or components which might be transformed into weapons later. Goods will also be examined, for example duty free merchandise or food and beverages for onboard consumption or airside bars and lounges.

This check is done by scanner machines leading to manual »frisking « only if a suspicious article is identified, for example the telltale silhouette of a handgun or a knife. The watchers are also on the lookout for a cluster of articles which might be the components necessary to construct a bomb: a triggering device, a source of energy for the ignition, the connecting wires and of course the explosive material itself, which on its own is fiendishly difficult to detect - especially in the very small amounts deemed sufficient to destruct an aircraft in flight (less than $100 \mathrm{~g}$ in the case of high performance military material). Passengers may be monitored by hidden cameras to detect unusual behaviour due to nervousness, sometimes sniffer dogs trained to find explosives will be deployed.

\subsection{A Bottleneck Problem}

In any case such a security checkpoint forms an irritating bottleneck, slowing the flow of passengers and giving headaches to airport planners and airline managers. There is a debate whether the survey technique known as profiling should be used in this context: concentrating search efforts on persons belonging to a demographic group with an above average probability of terrorist activism (say young men with dark eyes) would speed up the process, as non-suspicious travellers (elderly ladies of fair complexion) could pass through a fastline with just a quick perfunctory check.

But in Europe and North America this kind of passenger profiling is hardly used in practice: it could be regarded as an unjust discrimination against the selected demographic/ethnic group, leading to anger and frustration - and thus maybe even aiding the recruitment of new terrorists. On the other hand profiling is mistake-prone: terrorists can pay innocent-looking people to carry weapons to an air-side waiting room while the suspicious-looking attackers themselves enter the sensitive area »clean « and then take over the material.

But profiling in regard to behaviour rather than to demographic criteria can be helpful. A passenger booked on an intercontinental flight with a one-way ticket paid in cash and without any luggage probably deserves a closer look. Watching out for very nervous persons can also give hints towards the need of closer inspection, thus detecting not only potential terrorists but also drug-smugglers or criminals on the run. A suicide-bent jihadist is not a cool professional gangland killer, but rather a semi-deranged desperate expecting to go to his paradise in the next few hours - he will be under considerable and detectable psychic stress.

\section{Air Cargo in the Terrorists Focus}

\subsection{Why Attack Cargo?}

Generally air-side sealing at the airport has proved quite effective, although it is troublesome and sometimes humiliating for the travelling public. Strike attempts against civil aviation have been in decline, but due to its symbolic value an airliner still is a most attractive target for terrorists. But there is a door still slightly open for sabotage: air cargo. Contrary to public perception not all cargo pieces aboard an airplane - even a passenger plane - have undergone a security check by the authorities in the past (Gehrke 2010).

Smuggling an explosive device aboard an airplane via the cargo hold has distinct advantages from the terrorist viewpoint: 
- the perpetrator will be far away from the explosion, with a good chance of getting away undetected,

- the barriers to access are easier to surmount than the strict protection measures in passenger traffic, because there are many parties involved in transport and transfer,

- with hundreds of packages of different sizes, forms, weights, origins and destinations consolidated on a palette or in a container the sheer volume of material makes it almost impossible to examine them all.

On the other hand one cannot know exactly on which flight a consignment will travel, so it is hard to specify a target and to prime a time-bomb accordingly. An explosion in an airport warehouse would be a disappointing counter-climax from the terrorist point of view. Assaulting aviation from the cargo angle requires diligent planning and some knowledge about this business.

\subsection{A Wake-Up Call in 2010}

In October 2010 two parcels containing computer printers with explosives hidden in the toner cartridge were sent from Yemen to addresses in Chicago. They were intercepted - the first at a UK airport and the second in Dubai - after security forces had a tip-off from a turncoat informer. The terrorists probably had checked out the routes such packages would take by sending some goods in September and following their path via Internet-tracking (Gebauer 2010).

Air cargo carriers and integrators offer their customers tracking of their relevant shipments: by using a special password the customer can get a sneak view into the cargo carriers computer-system and gain detailed information in which phase of the voyage his parcel is at the moment (e. g. »truck-to-the airport «, » warehouse «, »airplane «, »truck-from-the-airport «, »final destination «).

The Yemen incident proved to be a wake-up call for security authorities in Europe and the USA. A catastrophe was avoided by luck alone: even after the information on the bomb had been acquired it proved difficult to stop its progress. When it was finally retrieved in East Midlands airport in Great Britain the experts were at first unable to find the explosives hidden in the dusty material in the toner cartridge. "Just in case « they disjointed the cartridge from the printer thus unwittingly defusing the bomb set to explode three hours later. After this incident air cargo security gained high priority status. As is often the case in dramatic near-misses many ideas for improvement were offered. But most of them would not work at all, work only against a threat

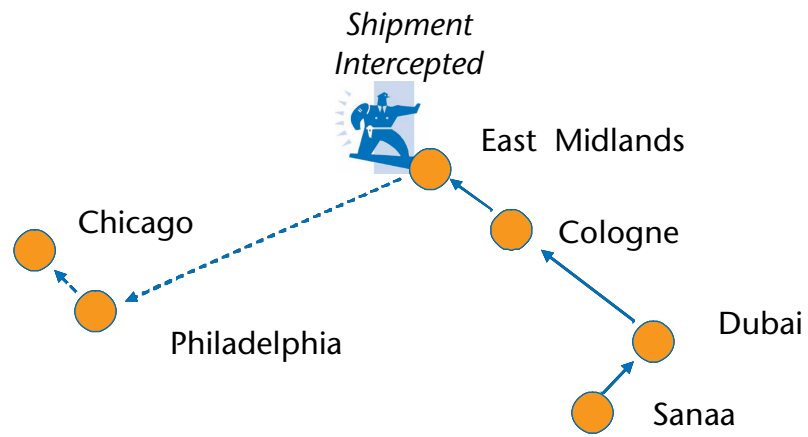

Figure 4: Route of first Yemen Air Cargo Bomb (dotted line: planned further route)

exactly identical to the Yemen incident, or would disrupt air cargo and world trade in a manner even worse than a successful hit had done. Some politicians for example suggested a general ban of cargo in a passenger plane belly (Gebauer 2010).

\section{Assessing Risks in Air Cargo}

\subsection{Security Relevant Characteristics}

Analysing the security risks in air cargo we may profit from the lessons learnt in passenger transport. But actually there is only one thing that passengers and cargo have in common: both are transported in aircraft. In most other aspects the transport of cargo is quite a different kind of business (Otto 2005):

- Cargo needs a parallel flow of information (freight bill in paper or as a data set) with the physical goods (the shipment itself), whereas passengers are intelligent agents knowing their way by carrying the necessary information with them (memorized flight schedule, ticket);

- Cargo has to be handled and carried for each transaction, passengers walk to/from the plane on their own;

- Cargo has its customers only at the point of origin and/or destination (sender and consignee), in passenger transport the customer is also the »item in transport «;

- Cargo comes in very different forms (sizes, weights, need of temperature control or special care as dangerous goods or living animals), passengers are quite homogenous in comparison and can be fitted in one standardized »loading unit « - the seat;

- Cargo shipments often are bundled in palettes or containers, so that a small parcel is hard to identify 
and isolate, individual passengers on the other hand will always be identifiable;

- Cargo will travel on its pre-determined path, the customer will not change his plans after sending his shipment, passengers are flexible and may decide to change their connections at any point during their trip;

- Cargo is tolerant against changes of flights and routings by the carrier, passengers will have to be persuaded to change their plans if the airline so desires;

- Cargo is almost exclusively a business-to-business venture, in passenger services you have to deal with companies - sending business travellers - as well as individual consumers or consumer groups in the case of leisure travel (Otto 2005).

\subsection{Profiling Shipments}

Air cargo security could be achieved without seriously disrupting international trade flows - at least in theory: if a thorough check of the documentation is realized, there is no need to inspect the physical goods if the integrity of the shipment can be guaranteed in every stage of the journey - ensuring that it contains exactly what the documentation claims.

In this business-to-business environment the vast majority of transactions will be done by a relatively small number of major customers. Routine shipments delivered by trustworthy partners (companies, forwarders) can be regarded as safe, as far as it is assured that these shippers have taken all the necessary precautions to protect their merchandise against third-party manipulation. Air cargo customers with a certified security system - called »known shippers « - can have their container units and shrink-wrapped palettes accepted without closer inspection (Elias 2007). Of course a monitoring of their security systems by the authorities will be necessary and regular checks of samples will be performed, but the bulk of shipments may flow without time-consuming physical screening. Only packages brought in by customers not in the »known shipper « database have to be examined in detail.

In air cargo profiling of shipments can be done without damaging the dignity of demographic groups by discrimination. This can be illustrated by default in the Yemen incident: why would someone send office equipment from this country (which does not manufacture any) to Jewish institutions in the USA? Nobody thought of asking this simple common-sense question as the parcels were accepted.
Airlines could install computer program screening their airway bills with an algorithm designed to detect suspicious patterns and so identify candidates for a closer look by human experts at the documentation and an X-ray device at the physical goods. Programs of this kind are already available in other areas of security: credit card companies for example detect sudden changes of behaviour in the card use pattern of their individual customers and take this as an indicator of theft or fraud. But this idea seems stymied by the fact that documentation in air cargo is still predominantly done in paper and not in electronic form (Ehrler 2011).

\subsection{Ensuring Integrity}

A parcel bound to travel aboard a plane goes a long way without much chance of close observation. Traditional security measures were focussing on the danger of theft - someone taking something out of the shipment. But in our context the main danger is that of someone putting something in - a bomb. Putting all merchandise in a locked container and wrapping all open palettes with shrinking foil is common practice. Special seals will also be applied, »electronic seals« using RFID-technology are becoming very popular. But as weight is an issue in aeronautics, an air cargo container is a lightweight construction and not a fortified vault, so a chance for tampering will remain.

There is an additional risk to integrity: in Europe a huge amount of air cargo is transported by trucks, as only wide-body aircraft offer sufficient capacity for carrying it. The long-range routes served by these aircraft are concentrated on a small number of big airports like Frankfurt, Amsterdam or Paris. To offer a convenient "cargo product « all over the country the airlines operate »road feeder «-services: shipments can be delivered to a local airport to be transported by a truck operated under the responsibility of the airline (with a »flight number «) to the main airport, where it is transferred to the long haul-service. Usually there is no threat to cargo integrity »in-flight « as long as a real airplane is the mode of transport. But if a container is accepted as air cargo and then has to travel $200 \mathrm{~km}$ on the road it can be the object of manipulation, if a truck driver takes a break or is an accomplice in the felony.

Securing integrity of the shipments by physical inspection before transferring it into a safe air-side warehouse is a time-consuming difficult task, so all the participants in the transport chain have tried to avoid it, for example by using the »known shipper«-regulation. 
In the last few years new machines have become available for physical screening by X-ray or similar technology up to »drive-through «-solutions, where trucks can pass under a special X-ray equipped arc (www.rapiscansystems.com). In the near future we may expect that all cargo items will be put to the same screening that carryon-bags have to undergo at the airport.

\subsection{Employees as a Risk Factor}

The gravest danger in security is the inside job - the participation of a member of the »victim organisation « in the crime. The probability of such an occurrence might be low, but the consequences would be very severe. In passenger services the risk of employee participation in terrorist acts should be negligible: ground crews - for example at the check-in gates - have to work with a lot of communication between team members as well as customers. It is not very probable that the smiling airline staffer giving out the boarding pass will smuggle a bomb into a suitcase the passenger just handed over. A terrorist playing the role of a loyal employee in this environment is rather hard to imagine.

The situation is quite different in cargo operations: all items have to be moved and will be stored for hours or even days. This puts up a hazard not only during the journey to the airport but also inside the perimeter. There is a lot of manual labour to be done - and in a seasonal business many part-time helpers are involved. Why not persuade an employee with access to the goods to hide a little something in a container? It is a well known (although not widely published) fact that criminal gangs are quite successful in infiltrating air cargo operations where valuable and easy to conceal merchandise can be got at. Maritime ports and some international airports have a long tradition as hotspots for organized crime (www.mafiatoday.com).

Terrorists might entrap a bona-fide worker into cooperation by bribe or blackmail. They could also apply for jobs with an appropriate set of forged (or even real) papers. Of course there are screening processes for all people aspiring to work inside an airport, but until now this has not been a very diligent check for low-level cargo workers never bound to come near the airplanes.

Infiltrating an air cargo facility in preparation for an attack still looks a realistic scenario. In most European countries it would not be too difficult to find suitable individuals with a clean curriculum vitae and let them work innocently for several months until they know their ways around and the time has come to place an explosive device. Stricter screening of applicants is not a solution, because the political, social and ethical problems discussed in regard to profiling of passengers arise also if you look at employees. A young Muslim student sporting a big beard is looking for a summer job as a forklift operator in air cargo - should the human resource department turn him down just on the basis of general suspicion of bad intent?

\section{Conclusions and recommendations}

Fast and reliable intercontinental transport for people and goods today is a main prerequisite for global trade. In the past the obstacles to world trade have been technological (slow and fragile means of transport in the early days of ocean shipping) or administrative (duties and import restrictions). By overcoming these obstacles the world has gained huge economic benefits. They are endangered by terrorist threats - and by the risk of overtightening the security reigns out of fear. International air passenger travel shows us that an acceptable balance between freedom to travel and security can be found despite a high level of menace.

Because almost everybody has some personal experience of travel benefits and drawbacks, passenger air transport easily caught the attention of the public and the media. On the other hand people hardly ever spent a thought on air cargo. In the last few years the growth of global trade has made it much more visible - but unfortunately also to the wrong people: today terrorists are aware of the option to strike civil aviation by placing a bomb in the air cargo flow. The scheme originating from Yemen in 2010 failed - not because security measures were functioning well, but due to happenstance in form of an insider tip-off.

In passenger air transport a high level of protection against hi-jacking and bombing was implemented by a coordination of international effort. In air cargo it should also be possible to build up a workable security system without killing off the business model and therefore encumbering global trade. A dedicated global security system has to be designed with the specifics of international air cargo in mind. But in cargo as well as in passenger services the solution will not be found by just improving technology, the human factor still poses the highest risks.

We may assume that after the Yemen incident terrorists will have evaluated the outcome and are planning 
a fresh attempt against a promising target - say a longrange passenger aircraft with a US or maybe European or Israeli flag. Sadly we have to live with a cruel arms race between terrorists and security, but fortunately security has scored far better in the long run - so far. But it is quite probable that the »other guys « are preparing for their next strike right now.

\section{Endnotes}

[1] This paper is based on presentations given by the author at the EBES Conference in June 2011 in Istanbul and the GARS-WIT Air Cargo Workshop in Wildau in October 2011.

\section{References Literature}

Biermann, T. (1986): Die Bedeutung des Luftverkehrs der »sechsten Freiheit« für den Wettbewerb im Luftverkehr. Düsseldorf.

Chiavi, R. (2005): Airfreight Development Supporting the Strategy of Global Logistics Companies. In: Delfmann et al.

Delfmann, W., Baum, H., Auerbach, S., Albers, S. (2005): Strategic Management in the Aviation Industry. Aldershot.

Ehrler, V. (2011): Beyond Supply-Chain Optimisation: Implications of Electronic Documentation on the Air Cargo System. GARS-WIT Air Cargo Workshop, Wildau 2011.

Gehrke, T. (2010): Sicherheitsrisiko Luftfracht in der Passage. MBAMaster Thesis, Wildau.

Maurer, P. (2006): Luftverkehrsmanagement. 4th ed., München.

Morrell, P. (2011): Moving Boxes by Air. Aldershot.

Otto, A. (2005): Reflecting the Prospects of an Air Cargo Carrier. In: Delfmann et al.

Pompl (2007): Luftverkehr. 5th ed., Berlin - Heidelberg - New York.

Reinhold, A., Becker, A., Phleps, P. (2011): Air Cargo 2030+ - Between Globalisation, Customer Behaviour and Environmental Regulations. GARS-WIT Air Cargo Workshop, Wildau.

Szöbb, U. (2011): Sicherheitsrisiko Luftfracht. MBA-Project Work (unpublished), Wildau.

Wensveen, J. (2007): Air Transportation. 6th ed., Aldershot.

\section{References Internet/World Wide Web}

Boeing World Air Cargo Forecast (2010), www.boeing.com, cited: 01.11.2010.

Brown, L. (2010): New Technology Can Dramatically Enhance Security and Thwart Terrorist Attacks, www.airliners.net, cited: 05.02.2010

Elias, B. (2007): Air Cargo Security - CRS Report for Congress, www.fas.or, cited: 05.01.2011.

Gebauer, M. (2010): World Scrambles to Tighten Air Cargo Security, www.spiegel.de, cited: 02.11.2010.

Kasarda, J., Green, J. (2004): Air Cargo - Engine for Economic Development, www.tiaca.org.

Shiell, C. (2002): Motives of Monsters, www.airliners.net.

\section{Author}

Prof. Dr. Thomas Biermann

Vorstandsvorsitzender des WIT - Wildau Institute of Technology/

Wildau Technical University of Applied Sciences

Fachbereich Betriebswirtschaft/Wirtschaftsinformatik

Technische Hochschule Wildau [FH]

thomas.biermann@th-wildau.de 
